\title{
Methadone Maintenance Reduces Heroin- and Cocaine- Induced Relapse without Affecting Stress-Induced Relapse in a Rodent Model of Poly-Drug Use
}

\author{
Francesco Leri*,', Annie Tremblay ${ }^{2}$, Robert E Sorge ${ }^{2}$ and Jane Stewart ${ }^{2}$ \\ 'Department of Psychology, University of Guelph, Guelph, Ontario, Canada; ${ }^{2}$ Center for Studies in Behavioral Neurobiology, Concordia University, \\ Montreal, Quebec, Canada
}

\begin{abstract}
Although it is well established that methadone can be an effective treatment for opiate addiction, it is not clear how methadone maintenance affects cocaine use and cravings in individuals who self-administer both opiates and cocaine. In our attempt to explore the effect of methadone maintenance on the effects of cocaine, we first assessed the locomotor stimulatory effects of cocaine in rats maintained on methadone (0, 10, 20, or $30 \mathrm{mg} / \mathrm{kg} /$ day, via osmotic minipumps). Chronic methadone elevated baseline locomotion in a dose-dependent manner and did not reduce the direct stimulatory effects of cocaine $(5 \mathrm{mg} / \mathrm{kg})$. We then investigated the effects of the highest methadone maintenance dose $(30 \mathrm{mg} / \mathrm{kg} /$ day) on heroin and cocaine seeking in extinction, and when it was precipitated by exposure to heroin, cocaine, or foot-shock stress in rats trained to self-administer both drugs in the same experimental context (heroin $0.05 \mathrm{mg} / \mathrm{kg} / \mathrm{inf}$; cocaine $0.5 \mathrm{mg} / \mathrm{kg} / \mathrm{inf}$, eight 3-h sessions each). In tests of reinstatement, rats responded selectively on the appropriate drug-associated lever after priming injections of heroin $(0.25 \mathrm{mg} / \mathrm{kg})$ or cocaine $(20 \mathrm{mg} / \mathrm{kg})$. Methadone maintenance blocked both cocaine- and heroin-induced reinstatement, but not stress-induced reinstatement, which was not lever selective. These results suggest that although methadone maintenance may not reduce the direct stimulatory effects of cocaine, it has the potential to reduce both spontaneous and cocaine-primed cocaine-seeking behavior.

Neuropsychopharmacology (2004) 29, 1312-1320, advance online publication, 24 March 2004. doi: I0.1038/sj.npp. I 300435
\end{abstract}

Keywords: heroin; cocaine; methadone; locomotion; relapse; stress

\section{INTRODUCTION}

The use of cocaine by opiate addicts is common, and its medical and social consequences are severe (Bux et al, 1995; Grella et al, 1995, 1997; Hausser et al, 1999; Hunt et al, 1984; Joe and Simpson, 1995; Kosten et al, 1986, 1987, 1988; Kreek, 1992a; Leri et al, 2004; Rowlett et al, 1997; Schutz et al, 1994; Strug et al, 1985; Torrens et al, 1991). Cocaine use also complicates the treatment of opiate addiction (Kleber, 1994; Kreek, 1997; Stark and Campbell, 1991) by increasing the likelihood of discontinuation of treatment and relapse (Broers et al, 2000; Dolan et al, 2001; Downey et al, 2000; Gossop et al, 2002; Perez et al, 1997).

A possible additional complication occurs when cocaineabusing opiate addicts enter methadone maintenance programs (Kolar et al, 1990). Methadone is a long-acting mu-opioid receptor agonist that is widely used for the

*Correspondence: F Leri, Department of Psychology, University of Guelph, Guelph, Ontario, Canada NIG 2WI, Tel: + 519824 4I20, ext 58264, Fax: + 5198378629 ,

E-mail: fleri@uoguelph.ca

Received 16 October 2003; revised 21 December 2003; accepted 29 January 2004

Online publication: 13 February 2004 at http://www.acnp.org/citations/ Npp02 $1303403474 /$ default.pdf treatment of opiate addiction (Kleber, 2003), and that has been demonstrated repeatedly to reduce opiate cravings and use (Greenwald, 2002; Joseph et al, 2000; Kling et al, 2000; Kreek, 1992b; Maxwell and Shinderman, 1999; Stimmel and Kreek, 2000).

Less clear, however, are the effects of methadone maintenance on cocaine abuse (Dunteman et al, 1992). In fact, clinical studies have reported that methadone decreases, has no effect, or even increases cocaine use, although differences in methadone dosage may account for the discrepant results (Borg et al, 1999; Brands et al, 2002; Chaisson et al, 1989; Condelli et al, 1991; Hartel et al, 1995; Kidorf and Stitzer, 1993; Kleber, 1994; Kosten et al, 1987; Magura et al, 1991; Maxwell and Shinderman, 1999; Strain et al, 1994). Given these mixed findings, it is surprising that few studies have investigated whether the motivational properties of cocaine are modified by methadone maintenance. Two studies in poly-drug abusing patients have reported that methadone increased responses to cocaine. Foltin et al (1995) found that patients maintained on methadone doses above $60 \mathrm{mg} /$ day reported larger cocaine effects on several measures, including ratings of cocaine liking. Similarly, Preston et al (1996) found that $50 \mathrm{mg} /$ day methadone maintenance enhanced cocaine-induced increases in subjective ratings of rush, good effects, liking, 
and desire for cocaine. Similar results have been obtained in animal studies. In rats, it has been reported that acute methadone injections $(8 \mathrm{mg} / \mathrm{kg})$ enhanced the reinforcing effects of cocaine, as established by the conditioned place preference paradigm (Bilsky et al, 1992). Finally, in nonhuman primates, it has been found that the combination of methadone and cocaine had greater reinforcing value than cocaine alone, as established by oral self-administration of these substances (Wang et al, 2001).

The demonstration of additive or synergistic interactions between methadone and cocaine is not surprising in light of their synergistic actions on neural mechanisms underlying incentive motivation. For example, acute doses of both methadone and cocaine elevate dopamine levels in the ventral striatum (Di Chiara and Imperato, 1988a, b; Pontieri et al, 1995; Spampinato et al, 1983; Wise et al, 1995) albeit via different mechanisms. When used in treatment settings, however, methadone is administered to achieve chronic exposure, not acute, and this is likely to modify its resulting neurochemical actions and, possibly, its interactions with cocaine (Bartoletti et al, 1983; Kling et al, 2000; Zhou et al, 1996). Furthermore, when maintained on appropriate doses, patients might be expected to use neither heroin nor cocaine if their desire for these drugs was effectively reduced by methadone (Dole, 1988; Dole et al, 1966). In other words, in theory, methadone should reduce drug cravings, and if drugs are used, it might also reduce their impact on subsequent drug-seeking behavior. Thus, a suitable experimental approach to the question of whether methadone can reduce cocaine abuse would employ a chronic regimen of methadone exposure and measure the effect of this treatment on spontaneous cocaine seeking and on cocaine seeking precipitated by drugs or stressors.

In these studies performed in rats, we first explored whether the direct psychomotor stimulatory effect of acute cocaine was modified by chronic methadone exposure via osmotic minipumps. In itself, methadone maintenance elevated locomotor activity in a dose-dependent manner, and did not reduce the stimulatory effects of cocaine. Then, on the basis of this dose-response study, we selected the highest dose of methadone for maintenance and determined whether it affected spontaneous heroin and cocaine seeking in rats trained to self-administer both drugs (Leri and Stewart, 2001). Finally, in the same rats, we studied the effect of methadone maintenance on extinction of responding for heroin and cocaine, and on heroin-, cocaine- and stress-precipitated reinstatement of heroin- and/or cocaineseeking behaviors.

\section{MATERIALS AND METHODS}

\section{Subjects}

Male Long-Evans rats (300-350 g, Charles River, Quebec) served as subjects. They were singly housed in a colony room on a reverse light-dark cycle (lights on 2000, light off 0800) and had free access to food and water at all times. All behavioral testing occurred between 0900 and 1700. The experimental procedures followed the guidelines of the Canadian Council on Animal Care and were approved by the Animal Care Committee, Concordia University.

\section{Surgery}

Osmotic minipumps. Chronic methadone exposure was achieved by implanting methadone-filled osmotic minipumps (s.c.). Rats were anesthetized with isoflurane and a small incision was made in the skin between the scapulae. Using a hemostat, a small pocket was formed by spreading the subcutaneous connective tissues apart. Osmotic minipumps (Alzet model 2ML2, $0.5 \mu \mathrm{l} / \mathrm{h}$ for 14 days, Durect Corporation, Cupertino, CA) were inserted into the pocket with the flow moderator pointing away from the incision. The skin incision was closed with wound clips. Using the same protocol for anesthesia, the pumps were removed upon completion of the delivery duration.

Intravenous catheterization. In the self-administration study, rats were prepared with intravenous silastic catheters (Dow Corning, Midland, MI) in the right jugular vein, under sodium pentobarbital anesthesia $(65 \mathrm{mg} / \mathrm{kg}$ i.p., MTC Pharmaceutical, Cambridge, Ontario). Just before surgery, rats were given atropine sulfate $(0.6 \mathrm{mg} / \mathrm{ml} ; 0.3 \mathrm{ml} / \mathrm{rat}$ s.c., MTC Pharmaceutical, Cambridge, Ontario) and, right after surgery, penicillin B (300 $000 \mathrm{IU}, 0.2 \mathrm{ml} / \mathrm{rat}$ i.m., WyethAyerst, Montreal, Quebec). The catheter was secured to the vein with silk sutures and was passed s.c. to the top of the skull where it exited into a connector (a modified 22-gauge cannula; Plastics One, Roanoke, VA) mounted to the skull with jeweler's screws and dental cement. A plastic blocker was placed over the opening of the connector during the recovery period and at all other times when the rats were not in a self-administration session. To prevent clogging, the catheters were flushed daily with saline and every third day with $0.1 \mathrm{ml}$ of a saline-heparin solution $(15 \mathrm{IU} / \mathrm{ml}$ heparin, ICN Biochemicals, Cleveland, $\mathrm{OH}$ ).

\section{Apparatus}

Locomotion chambers. Locomotor activity was monitored in a bank of 12 activity boxes. Each box $\left(20 \times 41 \times 25 \mathrm{~cm}^{3}\right)$ was constructed of white pressed wood (rear and two side walls), a wire screen ceiling, a Plexiglas front hinged door, and a tubular stainless-steel floor. Two photocells, positioned $3.5 \mathrm{~cm}$ above the floor and spaced evenly along the longitudinal axis of each box, were used to estimate horizontal locomotion. The activity boxes were kept in a room dimly lit with red lights, and they were controlled by a computer located in an adjacent room, running custommade software.

Self-administration chambers. In all, 18 Plexiglas operant chambers $\left(27 \times 27 \times 27 \mathrm{~cm}^{3}\right.$, custom made, Concordia University) were used in the self-administration experiment. Each chamber was enclosed in a larger $\left(87 \times 54 \times 43 \mathrm{~cm}^{3}\right.$, custom made, Concordia University) sound-attenuating plywood chamber. Each operant chamber had four levers (Med Associates, Lafayette, IN) located $10 \mathrm{~cm}$ above the floor: two retractable and two stationary. One of each type was located on opposite walls of the chamber, $10 \mathrm{~cm}$ apart from each other. The retractable levers (active levers) were connected to two infusion pumps for the delivery of drugs (Razel Scientific Instruments, Stamford, CT) positioned outside the sound-insulating 
chamber. The stationary levers served to control for baseline, nonreinforced, operant behavior; depression of these levers had no consequences (inactive levers), but all presses were recorded. There were two white light stimuli $3 \mathrm{~cm}$ above each active lever that came on for $30 \mathrm{~s}$ at the beginning of the session, and for the duration of each drug infusion, thus serving as discrete conditioned stimuli (CS) for drug delivery. Throughout the experiment, each selfadministration session was started by the activation of a red house light, which remained on for the duration of the session. Each self-administration chamber was fitted to deliver constant-current, intermittent, inescapable, electric foot-shock through a scrambler to the grid floor (Med Associates).

\section{Drugs and Dosages}

Heroin (diacetylmorphine $\mathrm{HCl}$ ) was obtained from Health and Welfare Canada, cocaine $\mathrm{HCl}$ was obtained from $\mathrm{DBH}$ Chemicals (Toronto, Ontario), and methadone HCL was obtained from Pharmascience (Montreal, Quebec); all drugs were dissolved in physiological saline.

For the locomotor activity study, four doses of methadone were used: $0,10,20$, and $30 \mathrm{mg} / \mathrm{kg} /$ day. In rats, it has been demonstrated that $20 \mathrm{mg} / \mathrm{kg} /$ day via osmotic minipumps results in $200 \mathrm{ng} / \mathrm{ml}$ serum methadone concentration (Zhou et al, 1996). In humans, a dose of $100 \mathrm{mg} /$ day results in an average hourly concentration of about $240 \mathrm{ng} / \mathrm{ml}$ (Kreek, 2000). Thus, the methadone doses chosen for our experiment were within therapeutic range (Dole, 1988; Maxwell and Shinderman, 1999). The dose chosen for the cocaine challenge was $5 \mathrm{mg} / \mathrm{kg}$ (i.p.), and the decision was based on previous studies indicating that, at this dose, cocaine induces significant elevations in locomotor activity in rats chronically exposed to heroin (Leri et al, 2003).

The highest maintenance dose of methadone tested in the activity study ( $30 \mathrm{mg} / \mathrm{kg} /$ day) was used in the self-administration experiment because it was well tolerated and it did not depress locomotor activity. More importantly, clinical studies have indicated that high methadone doses must be used in order to reduce both opiate and cocaine use (Borg et al, 1999). The doses used for self-administration were $0.05 \mathrm{mg} / \mathrm{kg} / \mathrm{inf}$ of heroin and $0.5 \mathrm{mg} / \mathrm{kg} / \mathrm{inf}$ of cocaine. These were selected on the basis of our findings, indicating that animals trained to self-administer both heroin and cocaine, at these doses, will display comparable levels of heroin- and cocaine-seeking behaviors when tested in extinction conditions (Leri and Stewart, 2001). For reinstatement, doses of $0.25 \mathrm{mg} / \mathrm{kg}$ (s.c.) of heroin and $20 \mathrm{mg} / \mathrm{kg}$ (i.p.) of cocaine were selected on the basis of studies showing that they can effectively reinstate heroin- and cocaine-seeking behavior in animals trained to self-administer both (Leri and Stewart, 2001).

\section{PROCEDURES}

\section{Locomotor Activity Experiment}

Three locomotor activity tests were given, and in each test behavior was monitored for $2 \mathrm{~h}$. The first test (Baseline) was given before implantation of the minipumps. Following this test, the rats were assigned to four groups ( $n=18$ per group) matched on baseline activity. Groups received minipumps releasing $0,10,20$, or $30 \mathrm{mg} / \mathrm{kg} /$ day of methadone immediately after the baseline test. The second test (Vehicle Test) occurred 6 days after implantation of the minipumps. Rats were brought to the activity chambers and injected with vehicle (ie physiological saline). The third test (Cocaine Test) occurred 13 days after implantation of the minipumps. For this test, nine rats from each group received a vehicle injection and the other nine rats an injection of $5 \mathrm{mg} / \mathrm{kg}$ of cocaine, $5 \mathrm{~min}$ before being placed in the activity chambers.

\section{Self-Administration Experiment}

For this experiment, which was conducted in two replications done several months apart, rats $(n=23$ in total) were trained to self-administer both heroin $(0.05 \mathrm{mg} / \mathrm{kg} / \mathrm{inf})$ and cocaine $(0.5 \mathrm{mg} / \mathrm{kg} / \mathrm{inf})$, but in separate self-administration sessions. Heroin and cocaine were available on alternative days, and each drug was associated with a particular lever and its associated light CS. Hence, over a total of 16 selfadministration sessions, each rat experienced eight sessions with heroin and eight sessions with cocaine.

For the 3-h self-administration sessions, the rats were moved from their home cages to the operant chambers and their connectors were attached to the infusion lines. At $10 \mathrm{~s}$ following the activation of a red house light, one of the two retractable levers was introduced, and the light CS associated with that lever was illuminated for $30 \mathrm{~s}$. Presses on the extended lever led to infusions of either heroin or cocaine, on a fixed ratio 1 (FR1) schedule of reinforcement. Drug was infused at a volume of $64 \mu \mathrm{l}$ during a 10 -s period. During an infusion, the appropriate light CS was illuminated for $10 \mathrm{~s}$. For each rat, one lever (delivering either heroin or cocaine in a session) was associated with continuous illumination of the light CS, and the other lever (delivering the alternate drug) was associated with a light CS flashing at a rate of $1 / \mathrm{s}$. Active lever presses during these 10 -s periods were recorded but did not lead to further infusions. Drug concentrations were adjusted for differences in body weight. The drug experienced first and the specific lever/light-drug associations were counterbalanced across rats. Responses on the inactive levers had no consequences, but all presses were recorded.

The day following the last self-administration session, 13 animals were implanted with methadone-filled minipumps $(30 \mathrm{mg} / \mathrm{kg} /$ day $)$, and the remaining 10 rats received sham surgery. The animals were then left undisturbed in their home cages for 5 days before the beginning of extinction.

For the extinction sessions, rats were returned to the operant chambers and their connectors were attached to the swivels, but not to the infusion lines. During these 3-h daily sessions, $10 \mathrm{~s}$ after the activation of the red house light, both retractable levers were introduced and the lights above them were illuminated for $30 \mathrm{~s}$. The rats were then free to press either of these levers or the inactive levers. Presses on the previously active levers activated the appropriate light CS, but no infusions were delivered. A total of six extinction sessions were given in 6 consecutive days.

Reinstatement sessions took place once a day, over a 3day period, and were similar to the extinction sessions, in that rats were free to respond on all levers, and presses on the previously active levers led to the activation of the 
appropriate light CSs, but not to the delivery of drug infusions. For the drug reinstatement sessions, rats were given priming injections of $0.25 \mathrm{mg} / \mathrm{kg}$ heroin (s.c.) or $20 \mathrm{mg} / \mathrm{kg}$ cocaine (i.p.), $5 \mathrm{~min}$ before the beginning of the session. On the first reinstatement test, half of the rats from each group (sham or methadone) received the heroin prime and the other half received the cocaine prime. On the second test day, half of the rats from each group received the alternate drug prime. Finally, on the third and last day of reinstatement, rats were exposed to $15 \mathrm{~min}$ of intermittent foot-shock stress $(0.8 \mathrm{~mA}, 0.5 \mathrm{~s} \mathrm{ON}$, a mean OFF period of $40 \mathrm{~s}$; Shaham et al, 2000)) and, immediately after the termination of foot-shock, the reinstatement session began with onset of the house light, the illumination of the light CSs, and the introduction of the active levers. All reinstatement sessions were $1 \mathrm{~h}$ long.

\section{Statistical Analyses}

Data were analyzed using two-way analysis of variance (ANOVA) with independent measures, two-way ANOVA with one repeated measure, and three-way ANOVA with two repeated measures, as well as $t$-tests for paired samples. Post hoc tests for differences between individual means were carried out using the Fisher's PLSD test for multiple comparisons $(p<0.05)$.

\section{RESULTS}

\section{Locomotor Activity}

No group differences were found at baseline (means \pm SEM: $0 \mathrm{mg} / \mathrm{kg} /$ day $=690.3 \pm 42.3 ; 10 \mathrm{mg} / \mathrm{kg} /$ day $=711.4 \pm 39.1 ; 20 \mathrm{mg} /$ $\mathrm{kg} / \mathrm{day}=689.9 \pm 39.8 ; 30 \mathrm{mg} / \mathrm{kg} / \mathrm{day}=692.6 \pm 42.1$ ), indicating that the groups were successfully equated for initial locomotor activity. It can be seen in Figure $1 \mathrm{a}$, however, that on the test for locomotor activity given 6 days after minipump implantation (Vehicle Test), chronic exposure to methadone dose dependently elevated locomotor activity $(\mathrm{F}(3,68)=9.2, p<0.0001)$.

Figure $1 \mathrm{~b}$ shows the results of the test given 13 days after implantation of the minipumps following either a vehicle or a cocaine challenge. Cocaine $(5 \mathrm{mg} / \mathrm{kg})$ elevated locomotion in all groups, and the ANOVA revealed significant main effects of both injection $(\mathrm{F}(1,64)=29.05, p<0.0001)$ and group $(F(3,64)=10.80, p<0.0001)$. The lack of significant interaction indicated that the increase in locomotor activity induced by acute injections of cocaine was similar in all groups, adding to the already existing elevation induced by chronic exposure to methadone. These data suggest that chronic methadone exposure did not modify the acute stimulatory effect of cocaine on locomotor activity.

\section{Self-Administration}

Rats developed reliable heroin and cocaine self-administration over the 16 training sessions. Figure 2a compares responses made on the active and inactive levers on these sessions when animals self-administered heroin $(0.05 \mathrm{mg} /$ $\mathrm{kg} / \mathrm{inf})$. The ANOVA revealed a significant main effect of lever $(\mathrm{F}(1,44)=36.23, p<0.0001)$, and multiple comparisons indicated that rats responded significantly more on the active lever on all heroin sessions. Figure $2 \mathrm{~b}$ compares responses made on the alternative active and inactive levers on these sessions when the same animals self-administered cocaine $(0.5 \mathrm{mg} / \mathrm{kg} / \mathrm{inf})$. The ANOVA revealed a significant main effect of lever $(\mathrm{F}(1,44)=62.07, p<0.0001)$, and multiple comparisons indicated that rats responded significantly more on the active lever on all cocaine sessions. At the conclusion of the self-administration period, methadone-filled minipumps $(30 \mathrm{mg} / \mathrm{kg} /$ day $)$ were implanted in 13 rats and the remaining 10 rats were subjected to sham surgery. The animals were left undisturbed in their home cages for 5 days before the beginning of the extinction sessions.

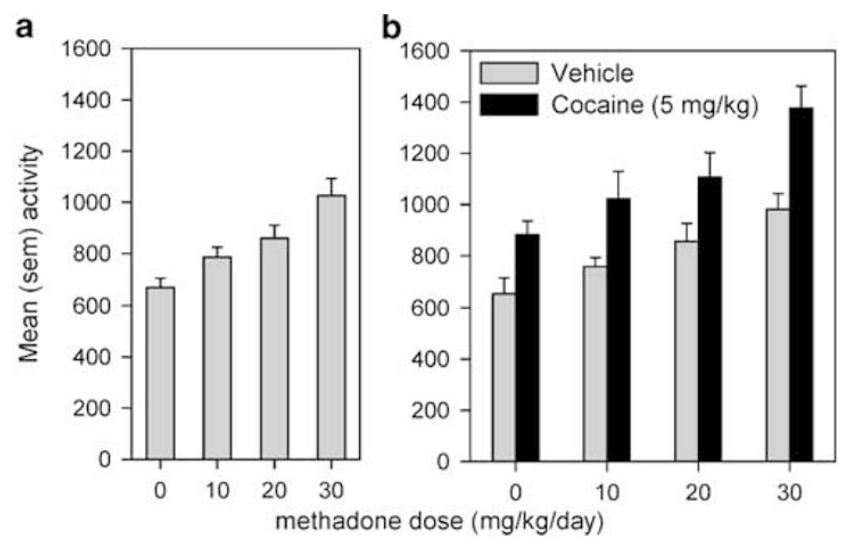

Figure I (a) Mean (SEM) locomotor activity in rats $(n=18$ in each dose group) tested 6 days after implantation of minipump releasing methadone (0. 10, 20, and $30 \mathrm{mg} / \mathrm{kg} /$ day). (b) Mean (SEM) locomotor activity in rats tested 13 days after implantation of the methadone-filled minipumps. Before the test, nine rats in each group received a vehicle injection, while the other nine rats received a cocaine injection $(5 \mathrm{mg} / \mathrm{kg})$. a

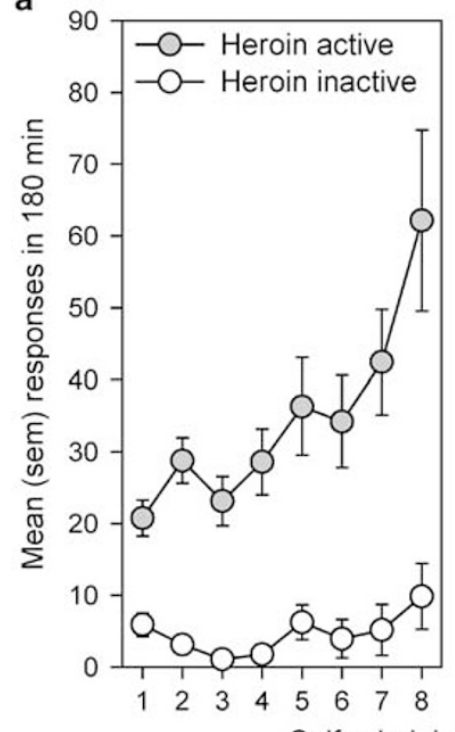

b

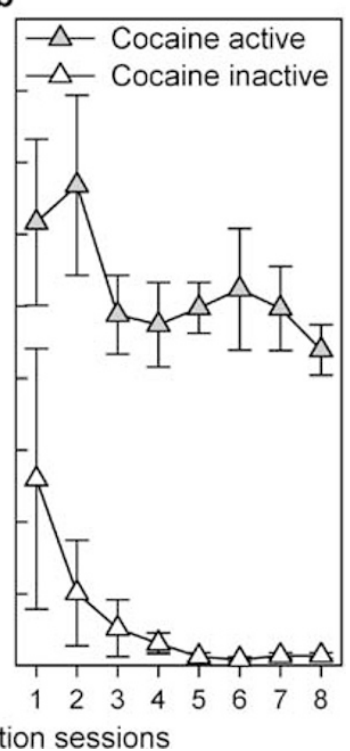

Figure 2 (a) Mean (SEM) responses made on the active and inactive levers in $180 \mathrm{~min}$, on sessions when animals self-administered heroin ( $0.05 \mathrm{mg} / \mathrm{kg} / \mathrm{inf}$ ). (b) Mean (SEM) responses made on the active and inactive levers in $180 \mathrm{~min}$, on sessions when animals self-administered cocaine (0.5 mg/kg/inf). 


\section{Extinction}

Figure 3 a shows the mean number of responses made by the sham- and the methadone-treated subjects on each of the 180-min extinction sessions, on both the heroin- and the cocaine-associated lever. A three-way ANOVA with group as the between factor and lever and extinction session as repeated measures indicated that, as expected given the doses of heroin and cocaine used (Leri and Stewart, 2001), there was no difference in the number of responses made on the two levers, although a significant decline was observed over extinction sessions $(\mathrm{F}(5,105)=10.86, p<0.001)$. This analysis also found no group differences in the number of responses made in the 180 -min-long extinction sessions. However, interesting differences were noted when group comparisons were performed on responding that occurred within the initial period of each extinction session, a period that best reflects the motivation of the animals to seek drugs (Fuchs et al, 1998; Markou et al, 1993).

Figure $3 \mathrm{~b}$ shows the mean number of responses made by the sham- and methadone-treated groups on the active lever
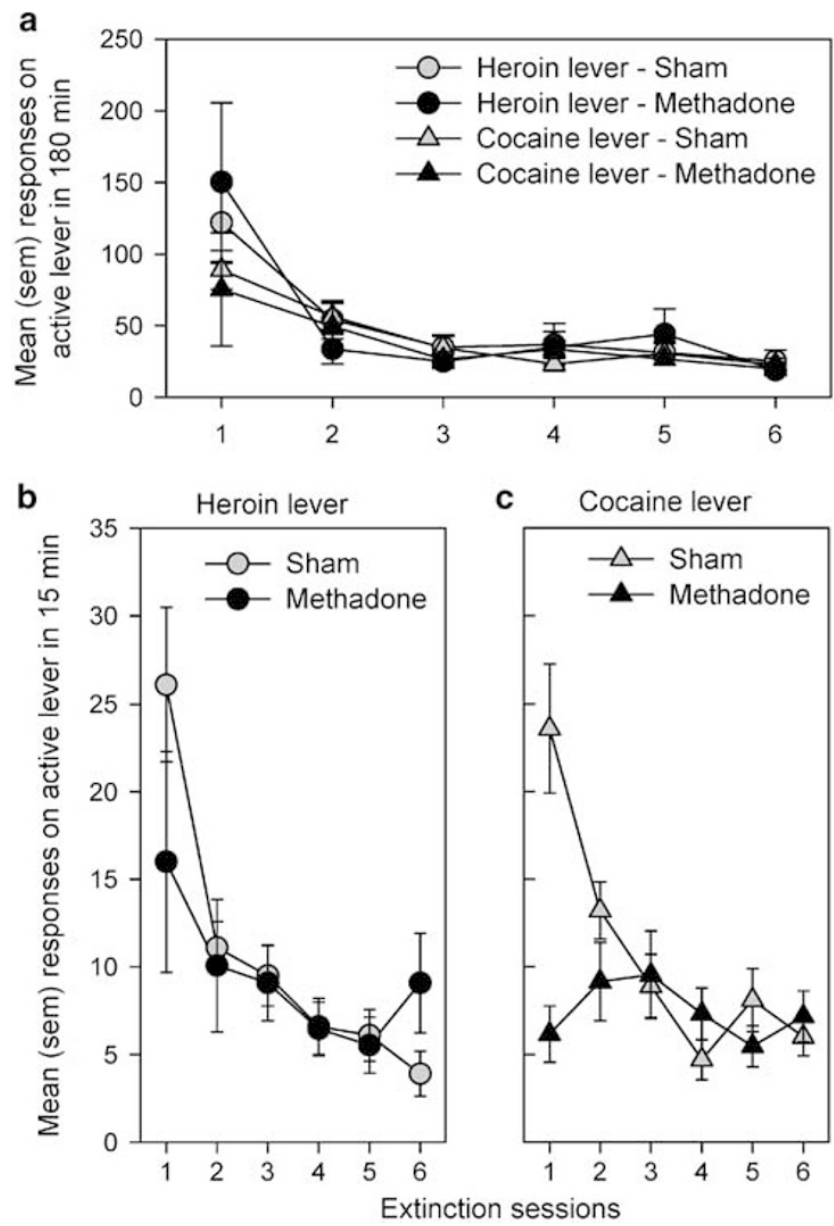

Figure 3 (a) Mean (SEM) responses made by the sham- and methadone-treated subjects in each 180-min-long extinction session, on both the heroin- and cocaine-associated levers. (b) Mean (SEM) responses made by the sham- and methadone-treated groups in the first 15 min of each extinction session, on the active lever associated with heroin infusions. (c) Mean (SEM) responses made by the sham- and methadone-treated groups in the first $15 \mathrm{~min}$ of each extinction session, on the active lever associated with cocaine infusions. associated with heroin infusions in the first $15 \mathrm{~min}$ of each extinction sessions. The ANOVA revealed a main effect of session $(F(5,105)=8.19, p<0.0001)$, but no significant group difference. Close inspection of the data suggested, however, that most animals treated with methadone showed less responding on the first extinction session than the sham-treated subjects, and that the large variability in the methadone group (see Figure $3 \mathrm{~b}$, session 1) was caused by one animal (number of responses on first session $=89$; group mean on first session without that animal = 9.92 \pm 2.6$)$. An ANOVA performed on the data with this rat removed revealed a significant group by session interaction $(\mathrm{F}(5,100)=6.12, p<0.0001)$ and multiple comparisons indicated that, on the first extinction session, methadone-treated rats responded significantly less than sham-treated rats on the heroin-associated lever.

Figure $3 c$ shows the mean number of responses made by the sham- and methadone-treated groups on the active lever associated with cocaine infusions in the first $15 \mathrm{~min}$ of each extinction sessions. The ANOVA revealed a significant group by session interaction $(\mathrm{F}(5,105)=9.67, p<0.0001)$ and multiple comparisons indicated that, on the first extinction session, methadone-treated rats responded significantly less than sham-treated rats on the cocaineassociated lever. No significant group differences were observed in responses made on the inactive levers during extinction.

\section{Reinstatement}

A three-way ANOVA with group as the between factor and lever and reinstatement as repeated measures was performed to assess whether heroin injections, cocaine injections, and foot-shock stress led to lever-selective reinstatement, and whether methadone maintenance modified the response to these stimuli. A significant group $\times$ lever $\times$ reinstatement interaction was found $(\mathrm{F}(2,48)=$ $4.81, p<0.05)$, and multiple comparisons indicated that priming injections of heroin reinstated responding selectively on the heroin-associated lever, and that priming injections of cocaine reinstated responding selectively on the cocaine-associated lever; the reinstatement induced by foot-shock was not lever selective (see Figures $4 \mathrm{a}$ and b). Multiple comparisons also indicated that both heroin- and cocaine-induced reinstatement was reduced in the methadone-treated group, but that methadone maintenance had no effect on stress-induced reinstatement. No significant group differences were observed in responses made on the inactive levers during reinstatement.

Separate analyses were performed to verify that heroin, cocaine, and foot-shock did indeed induce significant reinstatement in the sham-treated group. Responding on the heroin- or cocaine-associated lever induced by priming injections of heroin, cocaine, or foot-shock stress was compared to responding on the same lever during the first hour of the last extinction session. Statistical analyses confirmed that all treatments induced significant reinstatement of responding (heroin: $t(9)=2.19, p<0.05$; cocaine: $t(9)=2.31, p<0.05$; foot shock on heroin lever: $t(9)=2.33, p<0.05$; foot-shock on cocaine lever: $t(9)=2.22$, $p<0.05)$. 


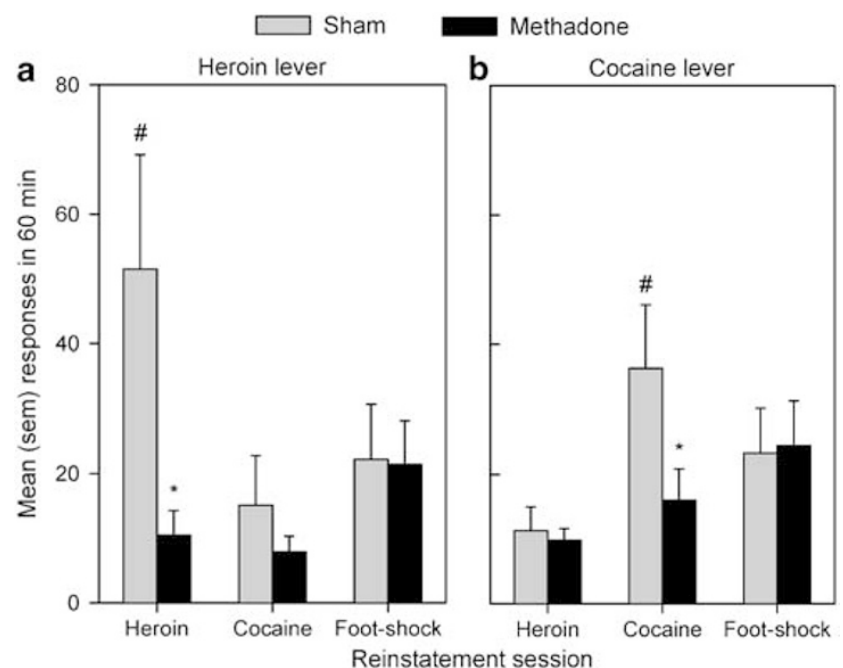

Figure 4 (a) Mean (SEM) responses made by the sham- and methadone-treated groups on each reinstatement session (60 min each), on the active lever associated with heroin infusions. (b) Mean (SEM) responses made by the sham- and methadone-treated groups on each reinstatement session (60 min each), on the active lever associated with cocaine infusions. ${ }^{\#} \mathrm{~A}$ significant difference between responding on the heroin- and the cocaine-associated levers. *A significant difference between responding displayed by the sham- and the methadone-treated groups.

\section{DISCUSSION}

The main finding of the present study is that methadone maintenance, at a relatively high dose, but one that did not reduce locomotor activity, attenuated heroin- and cocaineseeking assessed during extinction and after priming injections of heroin and cocaine. In the same animals, however, methadone was not effective in reducing the reinstatement of drug seeking induced by foot-shock stress. These results suggest that at sufficiently high doses, methadone maintenance has the potential to reduce both heroin and cocaine seeking, possibly by reducing the incentive value of drug-related cues, and if drugs are used, by reducing the impact of their use on subsequent drugseeking behavior (Leri and Stewart, 2002; Marlatt, 2002). For drug-seeking activated by stressful experiences, however, methadone appears to be ineffective, even at a relatively high dose.

The finding that methadone maintenance $(30 \mathrm{mg} / \mathrm{kg} / \mathrm{day})$ reduced responding on both heroin- and cocaine-associated levers selectively during the initial period of the first extinction session most likely reflects an increased latency to respond to drug-related cues (Fuchs et al, 1998) and not a methadone-induced impairment of general activity. In fact, when other rats were tested while maintained on this dose of methadone, they displayed increases in general activity relative to the sham-treated rats. Neither can the finding of reduced responding during the initial period of extinction be explained by interactions between drugs inasmuch as heroin and cocaine were not available. Therefore, based on previous interpretation of operant behavior during extinction (Markou et al, 1993; Fuchs et al, 1998; Mueller and Stewart, 2000; Leri and Stewart, 2001), we postulate that chronic mu-opioid receptor occupancy by methadone may have reduced the incentive motivational properties of heroin- and cocaine-related cues (ie levers and CSs associated with them), and thus reduced the tendency of rats to approach and make contact with these stimuli. The question remains, however, whether this suppression is due to specific effects on drug-related cues or to some more general motivational effect. It has been found, in fact, that chronic methadone treatment reduces the break point for food in rats responding on a progressive ratio schedule (Macenski et al, 1994), and this effect could not be explained by methadone-induced suppression of locomotor activity (Rudski et al, 1992). Future studies, therefore, should investigate the effect of chronic methadone maintenance on extinction of sucrose-motivated responding to determine whether the initial reduction in responding, which in the present study was replicated in two groups of animals run on separate occasions, is selective to heroin and cocaine seeking.

In the reinstatement tests, it was found that methadone decreased heroin-induced heroin seeking and cocaineinduced cocaine seeking. This effect of methadone maintenance on heroin-induced reinstatement replicates a previous finding showing that chronic exposure to heroin, via osmotic minipumps, reduced the effectiveness of heroin priming injections (Shaham et al, 1996). The effect of chronic methadone exposure on cocaine-induced reinstatement was somewhat surprising and, to our knowledge, it has not been reported before. It is known that acute administration of opioid agonists with activity at mu receptors such as butorphanol, etonitazene, and buprenorphine can attenuate cocaine-induced reinstatement (Comer et al, 1993; Lynch et al, 1998). These latter results, however, have been difficult to interpret because of the possibility that cocaine reinstatement was reduced by the depressant effects of acute opiate injections (Shalev et al, 2002). Our findings that locomotion was increased by methadone maintenance, and that acute injections of cocaine further enhanced locomotion, would appear to rule out this possibility and to support the conclusion that mu-opioid receptors agonists can indeed block cocaine-induced reinstatement. To our knowledge, it appears that chronic methadone maintenance is the only pharmacological manipulation capable of reducing, in the same animal, both heroin- and cocaine-induced reinstatement of drug seeking (Shaham et al, 2003; Shalev et al, 2002).

In the present study, it was also found that chronic methadone had no effect on foot-shock-induced reinstatement of responding, suggesting that methadone maintenance, in itself, may not be enough to protect against relapse induced by stress. The lack of effect of methadone maintenance on stress-induced reinstatement is in agreement with an early finding from this group, demonstrating that 'heroin maintenance' had no effect on foot-shockinduced reinstatement of heroin-seeking behavior (Shaham et al, 1996). Also, the present data are in agreement with previous reports that foot-shock-induced reinstatement is not blocked by opiate antagonists (Shaham and Stewart, 1996; Le et al, 1999; Liu and Weiss, 2002). Finally, it should be noted that the findings of the present study replicate our previous one showing drug priming-selective reinstatement of responding (Leri and Stewart, 2001), and further suggests that foot-shock stress reinstates responding in a nondrugspecific manner. This may be a reflection of the fact that 
different neural systems mediate relapse induced by drugs and induced by stress (Stewart, 2000, 2003).

In our laboratory, we have examined pharmacological interactions between chronic heroin exposure (via minipump) and acute injections of cocaine (Leri et al, 2003). In both the heroin study and the present study with methadone, we have consistently observed that chronic exposure to opiate drugs elevates locomotor activity in a dose-dependent manner and that the stimulatory effects of cocaine summate with those of the opiate drugs. It should not be surprising to find an additive effect of cocaine on locomotion induced by chronic opiate exposure in light of the known synergistic interactions between dopaminergic agonists (cocaine and amphetamine) and mu agonists on 6hydroxydopamine-induced rotation behavior (Kimmel and Holtzman, 1997), drug reinforcement (Bilsky et al, 1992; Duvauchelle et al, 1998; Mattox et al, 1997; Ranaldi and Munn, 1998; Rowlett et al, 1997; Wang et al, 2001), drug discrimination (Green-Jordan et al, 2001; Spealman and Bergman, 1992, 1994; Suzuki et al, 1997), elevation of dopamine concentration in the ventral striatum (Gerasimov and Dewey, 1999; Hemby et al, 1999), analgesia (Gatch et al, 1995; Kauppila et al, 1992; Misra et al, 1987; Nott, 1968; Shimada et al, 1988; Sierra et al, 1992), and drug toxicity (Blumberg and Ikeda, 1978; Leander and Lucot, 1977; Plunkett et al, 1989). It is surprising, however, that although chronic methadone maintenance did not reduce cocaineinduced stimulation of locomotion, it did reduce cocaineinduced reinstatement of cocaine seeking. This would not be the first demonstration of dissociation between neuronal events underlying cocaine-induced reinstatement and neuronal events involved in the acute reinforcing and the stimulatory effects of cocaine (Shalev et al, 2002). We are currently performing in vivo microdialysis studies to explore how dopamine activity in the ventral striatum is affected by cocaine administration in methadone maintained rats. Nevertheless, the present results suggest the interesting possibility that methadone maintenance may not reduce, and may even enhance, the direct stimulatory and/ or motivational properties of cocaine (Foltin et al, 1995; Preston et al, 1996) while, at the same time, it may reduce the priming effects of cocaine exposure on cocaine-seeking behavior, which may in turn reduce further cocaine use (Borg et al, 1999). In order to test this hypothesis, we are currently investigating the effects of methadone maintenance on the intravenous self-administration of cocaine, exploring how different doses of methadone modulate the self-administration of different doses of cocaine, and whether methadone prevents increases in drug-seeking behavior caused by 'lapses' to cocaine use (Leri and Stewart, 2002). Taken together, with our current results, it is hoped that these studies in animals will shed light on the clinical issue of whether appropriate methadone doses may reduce both opiate and cocaine abuse.

\section{ACKNOWLEDGEMENTS}

This research was supported by an Interdisciplinary Health Research Team (IHRT) grant from the Canadian Institutes of Health Research (CIHR) and grants from the Fond de la Recherche en Santé du Québec (FRSQ) and Fond pour la
Formation de Chercheurs et l'Aide à la Recherche du Québec (FCAR).

\section{REFERENCES}

Bartoletti M, Gaiardi M, Gubellini G, Bacchi A, Babbini M (1983). Long-term sensitization to the excitatory effects of morphine. A motility study in post-dependent rats. Neuropharmacology 22: 1193-1196.

Bilsky EJ, Montegut MJ, Delong CL, Reid LD (1992). Opioidergic modulation of cocaine conditioned place preferences. Life Sci 50: L85-L90.

Blumberg H, Ikeda C (1978). Naltrexone, morphine and cocaine interactions in mice and rats. J Pharmacol Exp Ther 206: 303-310.

Borg L, Broe DM, Ho A, Kreek MJ (1999). Cocaine abuse sharply reduced in an effective methadone maintenance program. $J$ Addict Dis 18: 63-75.

Brands B, Blake J, Marsh D (2002). Changing patient characteristics with increased methadone maintenance availability. Drug Alcohol Depend 66: 11-20.

Broers B, Giner F, Dumont P, Mino A (2000). Inpatient opiate detoxification in Geneva: follow-up at 1 and 6 months. Drug Alcohol Depend 58: 85-92.

Bux DA, Lamb RJ, Iguchi MY (1995). Cocaine use and HIV risk behavior in methadone maintenance patients. Drug Alcohol Depend 37: 29-35.

Chaisson RE, Bacchetti P, Osmond D, Brodie B, Sande MA, Moss AR (1989). Cocaine use and HIV infection in intravenous drug users in San Francisco. JAMA 261: 561-565.

Comer SD, Lac ST, Curtis LK, Carroll ME (1993). Effects of buprenorphine and naltrexone on reinstatement of cocainereinforced responding in rats. J Pharmacol Exp Ther 267: 1470-1477.

Condelli WS, Fairbank JA, Dennis ML, Rachal JV (1991). Cocaine use by clients in methadone programs: significance, scope, and behavioral interventions. J Subst Abuse Treat 8: 203-212.

Di Chiara G, Imperato A (1988a). Drugs abused by humans preferentially increase synaptic dopamine concentrations in the mesolimbic system of freely moving rats. Proc Natl Acad Sci USA 85: 5274-5278.

Di Chiara G, Imperato A (1988b). Opposite effects of mu and kappa opiate agonists on dopamine release in the nucleus accumbens and in the dorsal caudate of freely moving rats. J Pharmacol Exp Ther 244: 1067-1080.

Dolan MP, Black JL, Penk WE, Robinowitz R, Deford HA (2001). Predicting the outcome of contingency contracting for drug abuse. Behav Ther 17: 470-474.

Dole VP (1988). Implications of methadone maintenance for theories of narcotic addiction. JAMA 260: 3025-3029.

Dole VP, Nyswander ME, Kreek MJ (1966). Narcotic blockade. Arch Intern Med 118: 304-309.

Downey KK, Helmus TC, Schuster CR (2000). Treatment of heroindependent poly-drug abusers with contingency management and buprenorphine maintenance. Exp Clin Psychopharmacol 8: 176-184.

Dunteman GH, Condelli WS, Fairbank JA (1992). Predicting cocaine use among methadone patients: analysis of findings from a national study. Hosp Community Psychiatry 43: 608-611.

Duvauchelle CL, Sapoznik T, Kornetsky C (1998). The synergistic effects of combining cocaine and heroin ('speedball') using a progressive-ratio schedule of drug reinforcement. Pharmacol Biochem Behav 61: 297-302.

Foltin RW, Christiansen I, Levin FR, Fischman MW (1995). Effects of single and multiple intravenous cocaine injections in humans maintained on methadone. J Pharmacol Exp Ther 275: 38-47.

Fuchs RA, Tran-Nguyen LT, Specio SE, Groff RS, Neisewander JL (1998). Predictive validity of the extinction/reinstatement model of drug craving. Psychopharmacology 135: 151-160. 
Gatch MB, Negus SS, Butelman ER, Mello NK (1995). Antinociceptive effects of cocaine/opioid combinations in rhesus monkeys. J Pharmacol Exp Ther 275: 1346-1354.

Gerasimov MR, Dewey SL (1999). Gamma-vinyl gamma-aminobutyric acid attenuates the synergistic elevations of nucleus accumbens dopamine produced by a cocaine/heroin (speedball) challenge. Eur J Pharmacol 380: 1-4.

Gossop M, Stewart D, Browne N, Marsden J (2002). Factors associated with abstinence, lapse or relapse to heroin use after residential treatment: protective effect of coping responses. Addiction 97: 1259-1267.

Green-Jordan K, Warren L, Kantak KM (2001). Temporal factors affecting cocaine-opioid interactions: a cocaine drug discrimination study in rats. Psychopharmacology (Berl) 156: 427-434.

Greenwald MK (2002). Heroin craving and drug use in opioidmaintained volunteers: effects of methadone dose variations. Exp Clin Psychopharmacol 10: 39-46.

Grella CE, Anglin MD, Wugalter SE (1995). Cocaine and crack use and HIV risk behaviors among high-risk methadone maintenance clients. Drug Alcohol Depend 37: 15-21.

Grella CE, Anglin MD, Wugalter SE (1997). Patterns and predictors of cocaine and crack use by clients in standard and enhanced methadone maintenance treatment. Am J Drug Alcohol Abuse 23: $15-42$.

Hartel DM, Schoenbaum EE, Selwyn PA, Kline J, Davenny K, Klein RS et al (1995). Heroin use during methadone maintenance treatment: the importance of methadone dose and cocaine use. Am J Public Health 85: 83-88.

Hausser D, Kubler D, Dubois-Arber F (1999). Characteristics of heroin and cocaine users unknown to treatment agencies. Results from the Swiss Hidden Population Study. Soz Praventivmed 44: 222-232.

Hemby SE, Co C, Dworkin SI, Smith JE (1999). Synergistic elevations in nucleus accumbens extracellular dopamine concentrations during self-administration of cocaine/heroin combinations (speedball) in rats. J Pharmacol Exp Ther 288: 274-280.

Hunt DE, Lipton DS, Goldsmith D, Strug D (1984). Street pharmacology: uses of cocaine and heroin in the treatment of addiction. Drug Alcohol Depend 13: 375-387.

Joe GW, Simpson DD (1995). HIV risks, gender, and cocaine use among opiate users. Drug Alcohol Depend 37: 23-28.

Joseph H, Stancliff S, Langrod J (2000). Methadone maintenance treatment (MMT): a review of historical and clinical issues. $M t$ Sinai J Med 67: 347-364.

Kauppila T, Mecke E, Pertovaara A (1992). Enhancement of morphine-induced analgesia and attenuation of morphineinduced side-effects by cocaine in rats. Pharmacol Toxicol 71: t-8.

Kidorf M, Stitzer ML (1993). Descriptive analysis of cocaine use of methadone patients. Drug Alcohol Depend 32: 267-275.

Kimmel HL, Holtzman SG (1997). Mu opioid agonists potentiate amphetamine- and cocaine-induced rotational behavior in the rat. J Pharmacol Exp Ther 282: 734-746.

Kleber HD (1994). Assessment and treatment planning for cocaineabusing methadone-maintained patients. Treatment Improvement Protocol (TIP) from the U.S. Department of Health and Human Services Administration (DHHS), Publication No. (SMA) 94-3003.

Kleber HD (2003). Pharmacologic treatments for heroin and cocaine dependence. Am J Addict 12(Suppl): S18.

Kling MA, Carson RE, Borg L, Zametkin A, Matochik JA, Schluger J et al (2000). Opioid receptor imaging with positron emission tomography and [(18)F]cyclofoxy in long-term, methadonetreated former heroin addicts. J Pharmacol Exp Ther 295: $1070-1076$.

Kolar AF, Brown BS, Weddington WW, Ball JC (1990). A treatment crisis: cocaine use by clients in methadone maintenance programs. J Subst Abuse Treat 7: 101-107.
Kosten TR, Gawin FH, Rounsaville BJ, Kleber HD (1986). Cocaine abuse among opioid addicts: demographic and diagnostic factors in treatment. Am J Drug Alcohol Abuse 12: 1-16.

Kosten TR, Rounsaville BJ, Kleber HD (1987). A 2.5-year follow-up of cocaine use among treated opioid addicts. Have our treatments helped? Arch Gen Psychiatry 44: 281-284.

Kosten TR, Rounsaville BJ, Kleber HD (1988). Antecedents and consequences of cocaine abuse among opioid addicts. A 2.5-year follow-up. J Nerv Ment Dis 176: 176-181.

Kreek MJ (1992a). Effects of opiates, opioid antagonists and cocaine on the endogenous opioid system: clinical and laboratory studies. NIDA Res Monogr 119: 44-48.

Kreek MJ (1992b). Rationale for maintenance pharmacotherapy of opiate dependence. Res Publ Assoc Res Nerv Ment Dis 70: 205-230.

Kreek MJ (1997). Opiate and cocaine addictions: challenge for pharmacotherapies. Pharmacol Biochem Behav 57: 551-569.

Kreek MJ (2000). Methadone-related opioid agonist pharmacotherapy for heroin addiction. History, recent molecular and neurochemical research and future in mainstream medicine. Ann NY Acad Sci 909: 186-216.

Le AD, Poulos CX, Harding S, Watchus J, Juzytsch W, Shaham Y (1999). Effects of naltrexone and fluoxetine on alcohol selfadministration and reinstatement of alcohol seeking induced by priming injections of alcohol and exposure to stress. Neuropsychopharmacology 21: 435-444.

Leander JD, Lucot JB (1977). Toxic interactions of stimulants, narcotics and narcotic antagonists. Res Commun Chem Pathol Pharmacol 17: 255-264.

Leri F, Flores J, Rajabi H, Stewart J (2003). Effects of cocaine in rats exposed to heroin. Neuropsychopharmacology 28: 2102-2116.

Leri F, Stewart J (2001). Drug-induced reinstatement to heroin and cocaine Seeking: a rodent model of relapse in poly-drug use. Exp Clin Psychopharmacol 117: 21-27.

Leri F, Stewart J (2002). The consequences of different lapses on relapse to heroin-seeking in rats. Exp Clin Psychopharmacol 10: 339-349.

Leri F, Stewart J, Tremblay A, Bruneau J (2004). Heroin and cocaine co-use in a group of intravenous drug users in Montreal. J Psychiatry Neurosci 29: 40-47.

Liu X, Weiss F (2002). Additive effect of stress and drug cues on reinstatement of ethanol seeking: exacerbation by history of dependence and role of concurrent activation of corticotropinreleasing factor and opioid mechanisms. J Neurosci 22: 7856-7861.

Lynch WJ, Heaser WA, Carroll ME (1998). Effects of amphetamine, butorphanol, and morphine pretreatment on the maintenance and reinstatement of cocaine-reinforced responding. Exp Clin Psychopharmacol 6: 255-263.

Macenski MJ, Schaal DW, Cleary J, Thompson T (1994). Changes in food-maintained progressive-ratio responding of rats following chronic buprenorphine or methadone administration. Pharmacol Biochem Behav 47: 379-383.

Magura S, Siddiqi Q, Freeman RC, Lipton DS (1991). Changes in cocaine use after entry to methadone treatment. J Addict Dis 10: 31-45.

Markou A, Weiss F, Gold LH, Caine SB, Schulteis G, Koob GF (1993). Animal models of drug craving. Psychopharmacology 112: $163-182$.

Marlatt GA (2002). Do animal models provide a valid analogue for human drug lapse and relapse? Exp Clin Psychopharmacol 10: 359-360.

Mattox AJ, Thompson SS, Carroll ME (1997). Smoked heroin and cocaine base (speedball) combinations in rhesus monkeys. Exp Clin Psychopharmacol 5: 113-118.

Maxwell S, Shinderman M (1999). Optimizing response to methadone maintenance treatment: use of higher-dose methadone. J Psychoactive Drugs 31: 95-102. 
Misra AL, Pontani RB, Vadlamani NL (1987). Stereospecific potentiation of opiate analgesia by cocaine: predominant role of noradrenaline. Pain 28: 129-138.

Mueller D, Stewart J (2000). Cocaine-induced conditioned place preference: reinstatement by priming injections of cocaine after extinction. Behav Brain Res 115: 39-47.

Nott MW (1968). Potentiation of morphine analgesia by cocaine in mice. Eur J Pharmacol 5: 93-99.

Perez dlC, Trujols J, Ribalta E, Casas M (1997). Cocaine use immediately prior to entry in an inpatient heroin detoxification unit as a predictor of discharges against medical advice. $A m \mathrm{~J}$ Drug Alcohol Abuse 23: 267-279.

Plunkett LM, Seifen E, Kennedy RH (1989). Effects of morphine pretreatment on cocaine cardiotoxicity in anesthetized guineapigs. Arch Int Pharmacodyn Ther 297: 60-67.

Pontieri FE, Tanda G, Di Chiara G (1995). Intravenous cocaine, morphine, and amphetamine preferentially increase extracellular dopamine in the 'shell' as compared with the 'core' of the rat nucleus accumbens. Proc Natl Acad Sci USA 92: 12304-12308.

Preston KL, Sullivan JT, Strain EC, Bigelow GE (1996). Enhancement of cocaine's abuse liability in methadone maintenance patients. Psychopharmacology 123: 15-25.

Ranaldi R, Munn E (1998). Polydrug self-administration in rats: cocaine-heroin is more rewarding than cocaine-alone. Neuroreport 9: 2463-2466.

Rowlett JK, Negus SS, Shippenberg TS, Mello NK, Walsh SL, Spealman RD (1997). Combined cocaine and opioid abuse: from neurobiology to the clinic. NIDA Res Mon 178: 55-57.

Rudski JM, Schaal DW, Thompson T, Cleary J, Billington CJ, Levine AS (1992). Effects of methadone on free feeding in satiated rats. Pharmacol Biochem Behav 43: 1033-1037.

Schutz CG, Vlahov D, Anthony JC, Graham NM (1994). Comparison of self-reported injection frequencies for past 30 days and 6 months among intravenous drug users. J Clin Epidemiol 47: 191-195.

Shaham Y, Erb S, Stewart J (2000). Stress-induced relapse to heroin and cocaine seeking in rats: a review. Brain Res Rev 33: 13-33.

Shaham Y, Rajabi H, Stewart J (1996). Relapse to heroin-seeking in rats under opioid maintenance: the effects of stress, heroin priming, and withdrawal. J Neurosci 16: 1957-1963.

Shaham Y, Shalev U, Lu L, de Wit H, Stewart J (2003). The reinstatement model of drug relapse: history, methodology and major findings. Psychopharmacology 168: 3-20.

Shaham Y, Stewart J (1996). Effects of opioid and dopamine receptor antagonists on relapse induced by stress and reexposure to heroin in rats. Psychopharmacology 125: 385-391.

Shalev U, Grimm JW, Shaham Y (2002). Neurobiology of relapse to heroin and cocaine seeking: a review. Pharmacol Rev 54: 1-42.

Shimada A, Tsuda T, Yanagita T (1988). Mode of potentiating action of cocaine in morphine analgesia. Jpn J Pharmacol 48: 185-193.
Sierra V, Duttaroy A, Lutfy K, Candido J, Billings B, Zito SW et al (1992). Potentiation of opioid analgesia by cocaine: the role of spinal and supraspinal receptors. Life Sci 50: 591-597.

Spampinato U, Nowakowska E, Samanin R (1983). Increased release of striatal dopamine after long-term treatment with methadone in rats: inhibition by agents which increase central 5hydroxytryptamine transmission. J Pharm Pharmacol 35: 831-833.

Spealman RD, Bergman J (1992). Modulation of the discriminative stimulus effects of cocaine by $\mathrm{mu}$ and kappa opioids. $J$ Pharmacol Exp Ther 261: 607-615.

Spealman RD, Bergman J (1994). Opioid modulation of the discriminative stimulus effects of cocaine: comparison of micro, kappa and delta agonists in squirrel monkeys discriminating low doses of cocaine. Behav Pharmacol 5: 21-31.

Stark MJ, Campbell BK (1991). A psychoeducational approach to methadone maintenance treatment: a survey of client reactions. J Subst Abuse Treat 8: 125-131.

Stewart J (2000). Pathways to relapse: the neurobiology of drugand stress-induced relapse to drug-taking. J Psychiatry Neurosci 25: $125-136$.

Stewart J (2003). Stress and relapse to drug seeking: studies in laboratory animals shed light on mechanisms and sources of long-term vulnerability. Am J Addict 12: 1-17.

Stimmel B, Kreek MJ (2000). Neurobiology of addictive behaviors and its relationship to methadone maintenance. Mt Sinai J Med 67: $375-380$.

Strain EC, Stitzer ML, Liebson IA, Bigelow GE (1994). Buprenorphine versus methadone in the treatment of opioid-dependent cocaine users. Psychopharmacology 116: 401-406.

Strug DL, Hunt DE, Goldsmith DS, Lipton DS, Spunt B (1985). Patterns of cocaine use among methadone clients. Int J Addict 20: 1163-1175.

Suzuki T, Mori T, Tsuji M, Maeda J, Kishimoto Y, Misawa M et al (1997). Differential effects of mu-, delta- and kappa-opioid receptor agonists on the discriminative stimulus properties of cocaine in rats. Eur J Pharmacol 324: 21-29.

Torrens M, San L, Peri JM, Olle JM (1991). Cocaine abuse among heroin addicts in Spain. Drug Alcohol Depend 27: 29-34.

Wang NS, Brown VL, Grabowski J, Meisch RA (2001). Reinforcement by orally delivered methadone, cocaine, and methadonecocaine combinations in rhesus monkeys: are the combinations better reinforcers? Psychopharmacology 156: 63-72.

Wise RA, Newton P, Leeb K, Burnette B, Pocock D, Justice JBJ (1995). Fluctuations in nucleus accumbens dopamine concentration during intravenous cocaine self-administration in rats. Psychopharmacology 120: 10-20.

Zhou Y, Spangler R, Maggos CE, LaForge KS, Ho A, Kreek MJ (1996). Steady-state methadone in rats does not change mRNA levels of corticotropin-releasing factor, its pituitary receptor or proopiomelanocortin. Eur J Pharmacol 315: 31-35. 